\title{
Correction to "International Union of Pharmacology. LXXXIX. Update on the Extended Family of Chemokine Receptors and Introducing a New Nomenclature for Atypical Chemokine Receptors"
}

In the above article [Bachelerie F, Ben-Baruch A, Burkhardt AM, Combadiere C, Farber JM, Graham GJ, Horuk R, Sparre-Ulrich AH, Locati M, Luster AD, Mantovani A, Matsushima K, Murphy PM, Nibbs R, Nomiyama H, Power CA, Proudfoot AEI, Rosenkilde MM, Rot A, Sozzani S, Thelen M, Yoshie O, and Zlotnik A (2014) Pharmacol Rev 66:1-79], the title is listed incorrectly. The correct name is "International Union of Basic and Clinical Pharmacology."

The printer regrets this error and any inconvenience it may have caused. 